\title{
Tren Gaya Visual Logo Dan Pengaruhnya Terhadap Keabadian Penggunaan
}

\author{
Kankan Kasmana \\ Program Studi Desain Komunikasi Visual, Universitas Komputer Indonesia
}

\begin{abstract}
Abstrak. Logo berfungsi sebagai identifikasi, yang mampu membentuk dan menanamkan citra pada khalayak. Dengan gaya visual yang beragam logo mempunyai karakter yang berbeda-beda, memperlihatkan ciri, bentuk, dan selera. Bahkan logo-logo tertentu muncul memiliki gaya visual khas yang mencirikan gaya rancangan yang digandrungi oleh masyarakat pada saat logo tersebut dibuat. Adanya fenomena desain, berupa perubahan logo yang diakibatkan oleh pemilihan gaya visual tertentu yang disesuaikan tren menarik untuk diteliti. Dalam penelitian ini dibahas secara deskriptif desain logo dan kaitannya dengan tren serta keabadian penggunaannya.
\end{abstract}

Dapat disimpulkan dalam gaya visual logo, tren dipengaruhi oleh gaya ilustrasi dalam media, selera manusia, penemuan teknologi serta pengaruh sosial-budaya. Tren visual selalu berubah, dan mempengaruhi desain logo. Logo yang baik adalah logo berumur panjang dalam penggunaannya, ia dapat bertahan dalam perubahan tren yang ada. Tren hanya bertahan beberapa waktu saja, ia akan selalu berubah tergantung kondisi sosial-budaya masyarakat. Secara visual, desain logo yang mengikuti tren akan terasa generik, secara emosional ia tidak memberikan kesan yang beda bagi khalayak. Teknologi merupakan tools yang mengkomodir kebutuhan desainer, digunakan untuk merealisasikan konsepsi ide seorang desainer. Desain yang baik bukan desain yang dipenuhi oleh efek yang indah dan terlihat canggih yang dapat direalisasikan oleh teknologi, namun bagaimana desain itu menjadi solusi dari sebuah masalah.

Kata Kunci: Logo, Tren, Gaya Visual, Teknologi

\section{PENDAHULUAN}

Logo adalah salah satu bentuk dari identitas perusahaan. Logo berfungsi sebagai identifikasi, yang mampu membentuk dan menanamkan citra pada khalayak. Dengan citra tersebut logo menjadi lambang jaminan terhadap produk/jasa yang ditawarkan. Dalam konsep identitas tentang logo, nama dan logo menjadi identitas yang utama, oleh sebab itu logo menjadi ujung tombak dalam strategi pembentukan citra. Logo akan selalu muncul sebagai wajah pribadi perusahaan, dimanapun ia harus tampil, mulai dari media stationery, sarana promosi, interior perusahaan, seragam, bahkan menjadi perlambang budaya perusahaan. Maka 
tidak heran jika dalam rancangannya, logo dibuat sedemikian rupa dengan harapan citra positif.

Beberapa logo dibuat dengan proses yang cukup komprehensif, mulai dari riset pengumpulan data, analisis data, membuat strategi, menciptakan berbagai solusi, membuat konsep, hingga menciptakan visual. Dengan gaya visual yang beragam logo mempunyai karakter yang berbeda-beda. Karakter tersebut memperlihatkan ciri, bentuk, dan selera. Bahkan logo-logo tertentu muncul memiliki gaya visual khas yang mencirikan gaya rancangan yang digandrungi oleh masyarakat pada saat logo tersebut dibuat. Bentuk dan gaya logo banyak sekali dipengaruhi oleh kondisi sosial dan budaya masyarakat. Dalam sejarah desain, A.E.G. (Algemeine Electrizitås Gessellschaft) sebuah pabrik Elektro terbesar di Jerman pada awal abad 19 menjadi contoh ketika logonya bertransformasi bentuk dari gaya Historicism 1890 menjadi Art Nouveau (1900) kemudian gaya Modern (1907)

Perubahan sebuah logo bukan sesuatu yang sederhana, ia melibatkan banyak aspek, yang aspek tersebut sangat berpengaruh pada nilai ekonomi. Betapa tidak untuk merancang sebuah logo dibutuhkan biaya yang tidak sedikit. Terlebih jika pengerjaan tersebut dilakukan oleh sebuah biro desain terkenal. Selain itu ketika logo berubah, maka dibutuhkan promosi yang menginformasikan adanya perubahan logo, sehingga khalayak tidak terkelirukan dengan perubahan tersebut. Tentu saja promosi tersebut juga membutuhkan biaya. Hal lainnya yang sangat penting adalah ketika logo berubah maka bisnis pun di pertaruhkan, ada konsumen atau khalayak pengguna yang memiliki selera tertentu. Apakah dengan logo baru konsumen akan suka, atau sebaliknya. Atau apakah akan lebih percaya sehingga melakukan tindakan yang diinginkan oleh perusahaan misalnya melakukan pembelian atau justru sebaliknya.

Dengan latar belakang tersebut terkadang logo dibuat mengikuti selera pasar atau trend gaya visual yang sedang berkembang pada saat itu. Hal ini memunculkan masalah baru yakni citra perusahaan dalam bentuk visual yang akan terasa usang dalam masa-masa tertentu dimana tren gaya visual tertentu sudah hilang. Dalam 
penelitian ini akan dibahas mengenai desain logo dan tren visual, yang berpengaruh pada keabadian penggunaannya. Dengan studi kasus logo Universitas Komputer Indonesia dan Universitas Kristen Maranatha sebagai gambaran bagaimana secara visual keberadaan sebuah logo ditengah-tengah masyarakat. Dalam uraiannya dibahas secara umum berbagai logo dari beberapa institusi pendidikan di Indonesia

\section{METODE \& PEMBAHASAN}

Penelitian ini bersifat kualitatif, analisis deskriptif digunakan dalam penelitian ini, sebagai upaya menuturkan dan menafsirkan yang berkenaan dengan situasi yang terjadi, sikap dan pandangan yang menggejala di masyarakat, hubungan antarvariabel, pertentangan dua kondisi atau lebih, pengaruh terhadap suatu kondisi, perbedaan antar fakta (Sugiyono, 2006, h.21). Pada penelitian ini kasus ditelaah melalui pendeskripsian tentang logo, kemudian ditafsirkan berdasar pada deskripsi yang sudah dibuat sebelumnya. Berikut paparannya.

Identitas adalah salah satu metode untuk dapat dikenali, mengenali, dan membedakan satu hal dengan yang lain. Di dalam kehidupan, keberadaan identitas sangat diperlukan, tidak hanya manusia yang membutuhkan identitas tapi juga berbagai objek lain disekitar manusia. Dengan adanya identitas maka manusia bisa membedakan sesuatu (makhluk hidup maupun benda mati) tersebut dengan sesuatu yang lain.

Begitu juga dengan perususahaan institusi atau lembaga kesan sebuah lembaga/institusi tidak akan pernah lepas dari identitas. Identitas perusahaan merupakan suatu hal yang memungkinkan sebuah perusahaan dikenal dan mampu dibedakan dari perusahaan lainnya. Menurut Wally Olins (1989, h.29), bentuk identitas perusahaan terbagi menjadi 4 area aktivitas utama:

- Product/Service (apa yang dibuat/yang dijual),

- Environment (dimana membuat atau menjualnya-tempat-atau bentuk fisik), 
- Information (bagaimana menjelaskan dan mempublikasikan apa yang kita lakukan),

- Behaviour (bagaimana karakteristik interaksi khalayak didalam dan di luar organisasi perusahaan tersebut).

Sedangkan Balmer (1995) menjelaskan bahwa identitas perusahaan terdiri dari tiga bagian yang digunakan dalam bermacam cakupan:

- Corporate Visual (logo, uniform dsb.)

- Corporate Communication (iklan, public relations, informasi dsb.)

- Corporate Behavior (nilai-nilai internal, norma-norma dsb.)

Logo adalah salah satu bentuk dari identitas perusahaan. Logo berfungsi sebagai identifikasi, yang mampu membentuk dan menanamkan citra pada khalayak. Dengan citra tersebut logo menjadi lambang jaminan terhadap produk/jasa yang ditawarkan. Dalam konsep identitas tentang logo, nama dan logo menjadi identitas yang utama, oleh sebab itu logo menjadi ujung tombak dalam strategi pembentukan citra. Menurut Lori Siebert dan Lisa Ballad (1992, h.91), logo merupakan pengembangan sebuah simbol sehingga simbol tersebut dapat mengkomunikasikan identitas suatu perusahaan dimata khalayak. Logo akan selalu muncul sebagai wajah pribadi perusahaan, dimanapun ia harus tampil, mulai dari media stationery, sarana promosi, interior perusahaan, seragam, bahkan menjadi perlambang budaya perusahaan. Logo dibuat sedemikian rupa dengan harapan citra positif. Menurut Carter (2005) pertimbangan tentang logo yang baik itu harus mencakup beberapa hal diantaranya:

- Original \& Desctinctive, memiliki nilai kekhasan, keunikan, dan daya pembeda yang jelas

- Legible, memiliki tingkat keterbacaan yang tinggi meskipun diaplikasikan dalam berbagai ukuran dan media yang berbeda-beda.

- Simple atau sederhana, dengan pengertian mudah ditangkap dan dimengerti dalam waktu yang relatif singkat.

- Memorable, atau cukup mudah untuk diingat, karena keunikannya, bahkan dalam kurun waktu yang lama. 
- Easily associated with the company, dimana logo yang baik akan mudah dihubungkan atau diasosiasikan dengan jenis usaha dan citra suatu perusahaan atau organisasi.

- Easily adaptable for all graphic media. Disini, faktor kemudahan mengaplikasikan (memasang) logo baik yang menyangkut bentuk fisik, warna maupun konfigurasi logo di berbagai media grafis (cetak) perlu diperhitungkan pada proses perancangan.

Menurut (Lip, 1996: h.3-4) desain logo atau merek dagang sebaiknya memenuhi kondisi-kondisi sebagai berikut:

- Harus sesuai dengan kebudayaan.

- Logo harus menyandang citra yang diinginkan dan menunjukkan keadaan sebenarnya atau kegiatan dari perusahaan serta menggambarkan sasaran komersial organisasinya yang diwakilinya, sedangkan merek dagang harus didesain untuk mewakili produk suatu perusahaan.

- Harus merupakan alat komunikasi visual.

- Harus seimbang dan, karena itu, bisa dengan hitam putih atau seimbang dalam warna.

- Logo harus menggambarkan suatu irama dan proporsi.

- Harus artistik, elegan, sederhana namun memiliki penekanan atau titik fokus.

- Desainnya harus harmonis.

- Harus menggabungkan tulisan/huruf yang tepat sehingga dapat menyampaikan pesan yang dimaksud secara logis dan jelas.

- Harus menguntungkan secara Feng Shui dan seimbang dalam unsur yin dan yang.

Menurut Gregory Thomas (2000, h.18), ada 10 kriteria yang untuk diperhatikan dalam membuat logo dan simbol, diantaranya adalah :

- Visibility 
Akankah sebuah logo akan terlihat menonjol dalam sebuah lingkungan sekitarnya hingga dapat menghasilkan identifikasi cepat dan mudah diingat.

- Application

Seberapa fleksibel rancangan logo tersebut dapat diterapkan ke berbagai macam teknis aplikasi. Mempertimbangkan apakah logo muncul pada resolusi layar televisi atau harus diembos. Logo yang baik harus dapat diterapkan ke dalam berbagai teknik aplikasi.

- Distinctiveness

Akankah pengaplikasian logo dapat membedakan dirinya dengan kompetitor.

- Simplicity/Universality

Apakah konsep logo mudah untuk dikenali dan pertimbangan akan konotasi kebudayaan dan religius yang ditimbulkan.

- Retention

Jika sebuah logo terlalu mudah untuk dibaca maka target audience tidak akan mendapatkan rasa penemuan sehingga tidak akan terjadi interaksi personal yang berkesan.

- Color

Logo yang baik harus dapat diaplikasikan dalam hitam putih sehingga dapat melalui proses fotokopi atau fax.

- Descriptiveness

Apa logo tersebut mengungkapkan sifat (visi dan misi) dari perusahaan atau produknya. Logo yang baik dapat melakukan hal ini tanpa menggambarkannya secara berlebihan.

- Timelessness

Sebuah logo yang baik bisa bertahan setidaknya 15 - 20 tahun.

- Modularity

Dapatkah logo diadaptasikan keberbagai macam aplikasi. Hierarki harus diperhatikan dalam penerapkannya bersama tipografi serta elemen grafis lainnya. Semua elemen harus dapat saling mendukung untuk menciptakan komunikasi yang selaras. 


\section{- Equity}

Usia penggunaan dan pengenalan terhadap sebuat logo. Mengetahui kapan dan apa yang hendak dirancang ulang adalah perkembangan yang penting. Sebagai contoh akan sulit mengganti nilai yang telah terkandung dalam logo Coca-Cola.

Logo dihadirkan memiliki tujuan, Carter (2005, h. 8) menjelaskan tujuan tersebut diantaranya:

- Sebagai ciri khas dan identitas agar mudah dikenal oleh publik.

- Sebagai petunjuk karakter perusahaan di mata publik.

- Menginformasikan jenis usaha untuk membangun image.

- Merefleksikan semangat dan cita-cita perusahaan.

- Menumbuhkan kebanggaan di antara anggota perusahaan.

Sedangkan fungsi logo menurut John Murphy dan Michael Rowe (1998, h. 8) yaitu :

- Fungsi identifikasi: khalayak dapat mengidentifikasi perusahaan tersebut bergerak di bidang apa dan barang serta jasa apa yang dihasilkan.

- Fungsi pembeda: logo dapat membedakan perusahaan yang satu dengan perusahaan yang lain, produk yang satu dengan produk yang lainnya.

- Fungsi komunikasi: logo berperan sebagai pemberi informasi (jika berupa rambu-rambu), dan dapat juga menjadi pemberi tahu keaslian sebuah produk.

- Merupakan aset yang berharga. Jika produk tersebut lebih dikenal di negara-negara lain maka suatu perusahaan/merek akan dihargai dengan cara waralaba.

- Mempunyai kekuatan hukum. Logo yang telah diregistrasi dapat dijadikan jaminan kualitas produk yang dilindungi Undang-Undang.

Logo selain nama menjadi sebuah kebutuhan dan cara bagaimana sebuah perusahaan dapat dikenali. Schmit dan Simonson (1997, h.33) mengatakan ada beberapa alasan adanya kebutuhan akan penciptaan dan perubahan sebuah logo diantaranya:

- Adanya perubahan struktur organisasi 
- Adanya penurunan kesetiaan pegawai dan konsumen terhadap produk institusi atau lembaga

- Citra (perusahaan \& visual) yang sudah usang

- Logo dan citra yang tidak tetap

- Adanya kompetisi baru (munculnya kompetitor)

- Adanya perubahan prilaku konsumen terhadap produk/jasa

- Adanya peluncuran produk baru

- Adanya perluasan pasar

Logo bukan sekedar identifikasi, dan pembentuk citra, namun ia menciptakan ketertiban pembakuan dalam media komunikasi visual yang dikeluarkan oleh lembaga/institusi/perusahaan. Selain itu ia berfungsi media untuk mengkomunikasikan sebuah pesan pada khalayak yang menjadi target sasaran. Komunikasi tersebut disampaikan dalam bentuk visual (garis, bidang, bentuk, warna, tekstur), tipografi (huruf \& karakternya), tagline (slogan, motto dan lainlain). Ia muncul dalam sebuah gaya visual yang khas.

Gaya visual tersebut di pengaruhi oleh tren yang sedang terjadi. Dan gaya tersebut akan selalu berkembang sehingga memungkinkan adanya gaya-gaya visual yang lain. Menurut Henrik Vejlgaard (2007) "trend" boleh jadi digunakan sebagai sinonim dari "change" (perubahan) dalam nilai-nilai politik, spiritual, bisnis dan banyak bidang lainnya. Sebuah tren adalah sebuah proses yang digerakkan oleh umat manusia dalam pola sosiologis yang telah berlangsung berabad-abad. Tren merupakan sesuatu yang sedang "menjamur" atau disukai dan digandrungi oleh orang banyak pada suatu waktu tertentu. Dalam gaya visual logo, tren dipengaruhi oleh:

1. Gaya ilustrasi dalam media

Media merupakan 'mesin' yang memungkinkan tercipta dan tersebarluaskannya sebuah isu. ketika sebuah isu tersebut dimunculkan berulang-ulang maka ia akan menciptakan sebuah tren. Dalam desain ada gaya visual tertentu yang muncul pada waktu tertentu dan digandrungi, media menjadi jembatannya.

2. Selera manusia 
Selera manusia selalu berubah, ini merupakan karakterstik manusia sebagai mahluk sosial yang tidak pernah puas terhadap sesuatu.

\section{Penemuan teknologi}

Zaman berubah, hal baru ditemukan. Berbagai macam teknologi dikembangkan untuk mengatasi berbagai masalah dalam kehidupan. Dalam gaya visual logo, teknologi memungkinkan bentuk visual seperti apapun untuk diwujudkan. Kini bentuk-bentuk logo yang sulit akan dengan mudah diciptakan, penemuan software canggih dengan efek yang beragam mampu menciptakan gaya visual baru.

4. Pengaruh sosial-budaya

Kehidupan sosial budaya sangat mempengaruhi seseorang untuk menciptakan desain. Penggunaan warna, bentuk, serta gaya ilustrasi sangat dipengaruhi oleh keaadan sosial dan budaya masyarakat pada saat desain dibuat.

Di masyarakat dapat dijumpai bentuk logo yang mengikuti tren gaya visual yang dipengaruhi oleh keempat hal diatas.
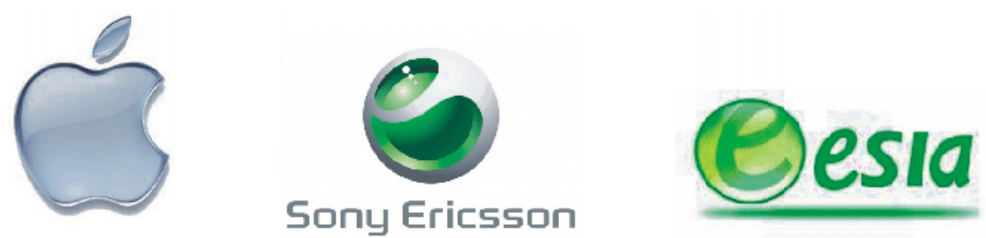

Gambar III.1 Gaya visual logo

Sumber: http://www.edibleapple.com/2009/04/20/the-evolution-and-history-of-the-apple-logo/ http://en.wikipedia.org/wiki/File:Sony_Ericsson_logo.svg

http://www.antarasumut.com/esia-gandeng-htc-kembangkan-bundling-internet-berkualitas (6 Januari 2011)

Gambar diatas memperlihatkan gaya visual logo yang dipengaruhi oleh konsep visual web 2.0, yang diluncurkan oleh O’Relly Media tahun 2004. Salah satu gaya visual web ini adalah rich surface, yakni visual yang kaya dengan bentuk yang terkesan bervolume, 3 dimensi, disebut sebagai web 2.0 style. Gaya ini berkembang mengikuti munculnya generasi baru situs internet dari web 1.0 menjadi web 2.0. lalu bagaimana dengan gaya visual logo di generasi web 3.0, dan selanjutnya?

Bentuk 3 dimensi ini juga merupakan contoh dari adanya selera manusia yang menginginkan bentuk yang lebih realistis. Menurut Stephen N. Elliot (1996), "people are more like the world as God made it." Hal ini mendefinisikan bahwa 
manusia menginginkan bentuk-bentuk yang realis, manusia menginginkan bentuk-bentuk seperti yang Tuhan ciptakan. Itu sebabnya bentuk yang bervolume (3D) lebih disukai daripada bentuk yang datar (2D). Berwarna lebih disukai dari hitam putih. Walaupun terkadang bentuk-bentuk tersebut diciptakan hanya 'seolah-olah' bukan bentuk yang sebenarnya. Itu sebabnya TV lebih menarik dibanding radio, TV hitam putih diganti oleh TV berwarna, TV high definition menggantikan TV analog dll. Begitu juga dalam gaya visual logo, bahwa logo dengan bentuk 'seolah-olah' 3D disukai ketimbang logo dengan tampilan 2 dimensi.

Bentuk logo diatas tentu saja akan mudah diciptakan jika teknologi memungkinkan. Penemuan software baru dengan efek yang canggih memungkinkan gaya visual tersebut dibuat. Perusahaan software terkenal Adobe cukup mengakomodir kebutuhan desainer, hingga saat ini Adobe sudah menciptakan beberapa generasi dari software grafis Adobe Illustrator dengan fitur-fiturnya sangat beragam.

Gaya visual diatas juga dipengaruhi oleh kondisi sosial dan budaya. Betapa tidak logo ini adalah logo dari produk-produk yang berhubungan dengan teknologi. Tentu saja logo tersebut dibuat secanggih mungkin. Alasannya adalah kondisi sosial masyarakat yang butuh akan sesuatu yang dapat memperlihatkan kesan canggih tersebut. Logo mengumumkan tentang apa yang ia citrakan, menjadi jaminan terhadap jasa/produk yang ditawarkan.

Namun akankah logo tersebut bertahan, seiring dengan munculnya generasi selanjutnya masihkan gaya visual tersebut digandrungi dan menjadi tren. Berikut ini gambaran perubahan logo pada perusahaan perusahaan besar di dunia, serta perusahaan Indonesia yang dipengaruhi oleh tren visual yang hadir pada saat logo tersebut dibuat. 


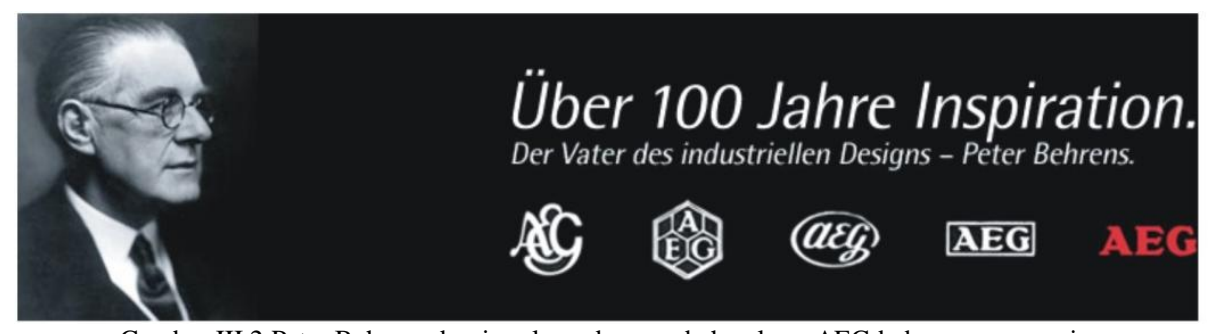

Gambar III.2 Peter Behrens desainer logo dan perubahan logo AEG beberapa generasi Sumber: http://www.dewebsite.org/logo/aeg/aeg.html (26 Januari 2011)

Dalam sejarah desain, A.E.G. (Algemeine Electrizitås Gessellschaft) sebuah pabrik Elektro terbesar di Jerman pada awal abad 19 menjadi contoh ketika logonya bertransformasi bentuk dari gaya Historicism 1890 menjadi Art Nouveau (1900) kemudian gaya Modern (1907). Perubahan logo terjadi karena adanya gaya visual yang digandrungi saat itu.

Ditanah air perubahan logo juga menjadi hal yang biasa, sekitar tahun 2000 RCTI merubah logonya dengan menghilangkan elemen garis, serta penyederhanaan bentuk logo. Pada saat logo ini dibuat (1989) elemen garis pada desain sedang disukai. Begitu juga dengan logo KFC yang mengalami beberapa kali perubahan.

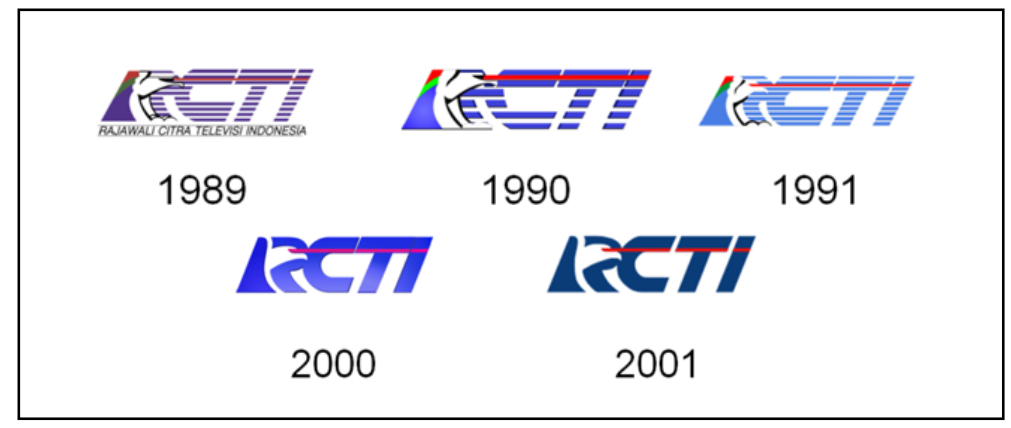

Gambar III. 3 Perubahan logo RCTI

Sumber: http://globaltvindonesia.wikia.com/wiki/File:RCTI_(Rajawali_Citra_Televisi_Indonesia)_Logo_History.png (23 Januari 2011) 


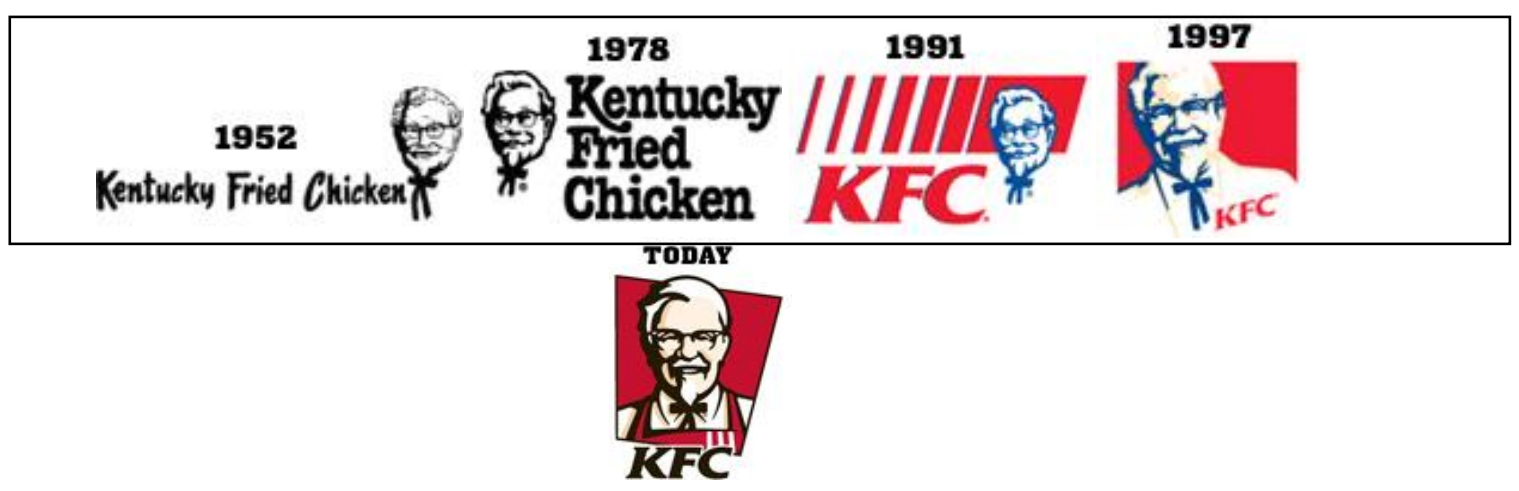

Gambar III. 4 Perubahan logo KFC

http://www.famouslogos.us/kfc-logo/ (23 Januari 2011)

\section{Tren Logo 2009}

Menurut Bill Gardner (2009) ada beberapa gaya visual logo yang menjadi tren dan ada juga yang mulai usang.

Sebagai contoh, berikut beberapa gaya visual logo yang menjadi tren tahun 2009 menurut Bill Gardner, yang ia kumpulkan dari bebagai belahan di dunia.

\section{Photofil}

Gambar hasil fotografi menjadi pilihan pada logo ini

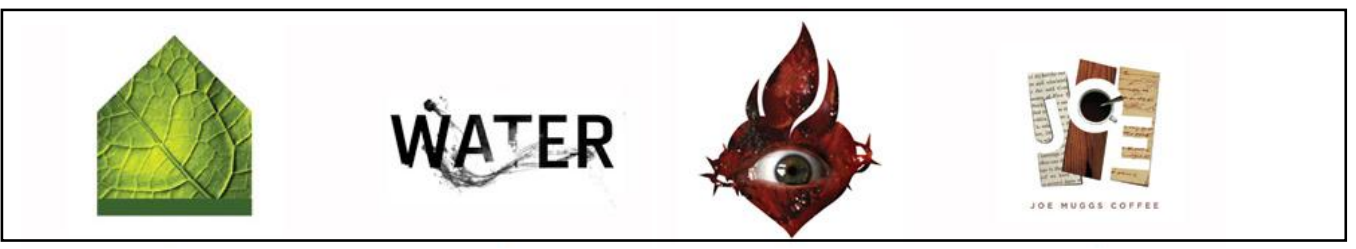

Gambar III. 5 Logo dengan gaya visual Photofill

Sumber:http://www.logolounge.com/article.asp?aid=kfP (3 Januari 2011)

\section{Concealed}

Gaya visual yang mengetengahkan bagian gambar tersembunyi yang dapat ditemukan dalam bentuk logo tersebut

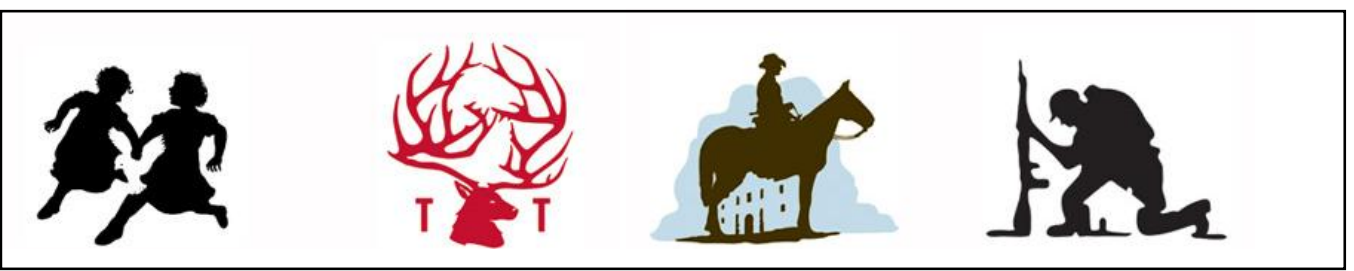

Gambar III. 6 Logo dengan gaya visual Concealed Sumber:http://www.logolounge.com/article.asp?aid=kfP (3 Januari 2011)

\section{VariDot}

Gaya visual yang merupakan komposisi dari kumpulan titik lingkaran. 


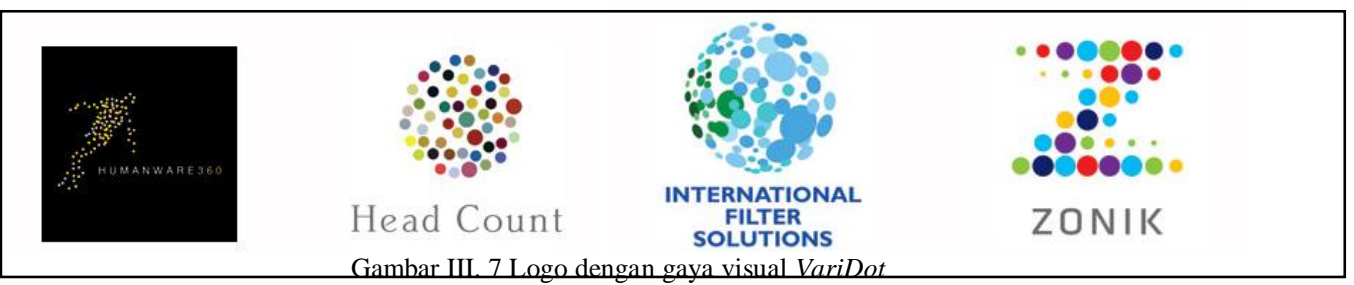

Sumber:http://www.logolounge.com/article.asp?aid=kfㅁ (3 Januari 2011)

\section{Candy Stripe}

Warna-warni permen, crayon menjadi konsep ide dalam gaya visual logo ini, mengingatkan pada masa ketika masih kecil.

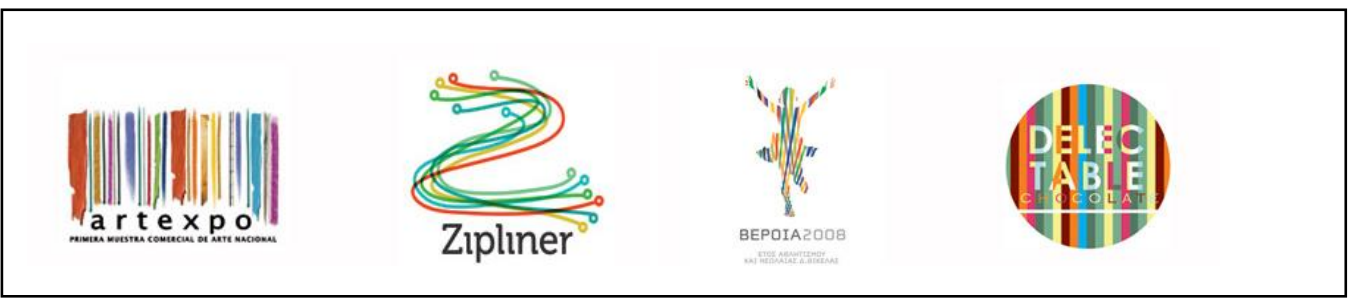

Gambar III. 8 Logo dengan gaya visual Candy Stripe

Sumber:http://www.logolounge.com/article.asp?aid=kfP (3 Januari 2011)

\section{Texting}

Gaya visual logo ini merupakan kombinasi antara teks dan ikon

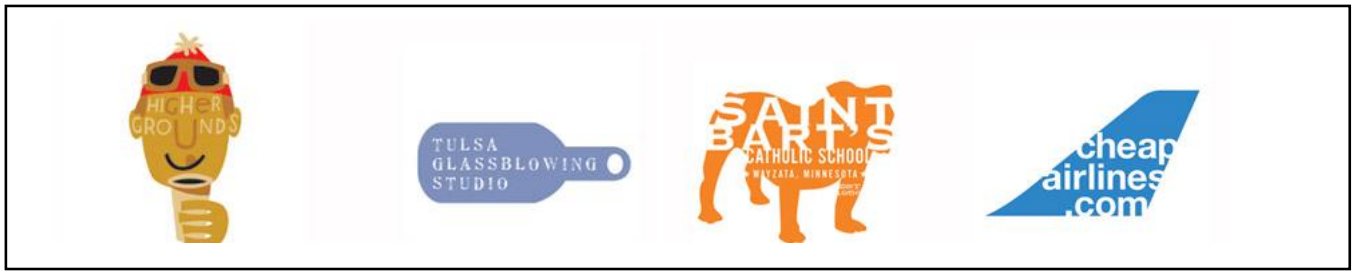

Gambar III. 9 . Logo dengan gaya visual Photofill

Sumber:http://www.logolounge.com/article.asp?aid=kfP (3 Januari 2011)

\section{Encrust}

Gaya visual yang unik,"One of something ugly is ugly. Many of something ugly is beautiful." Menurut Bill gaya ini muncul karena penggabungan sesuatu yang "ugly" menjadi sesuatu yang "beautiful". Muncul dalam tren logo tahun ini

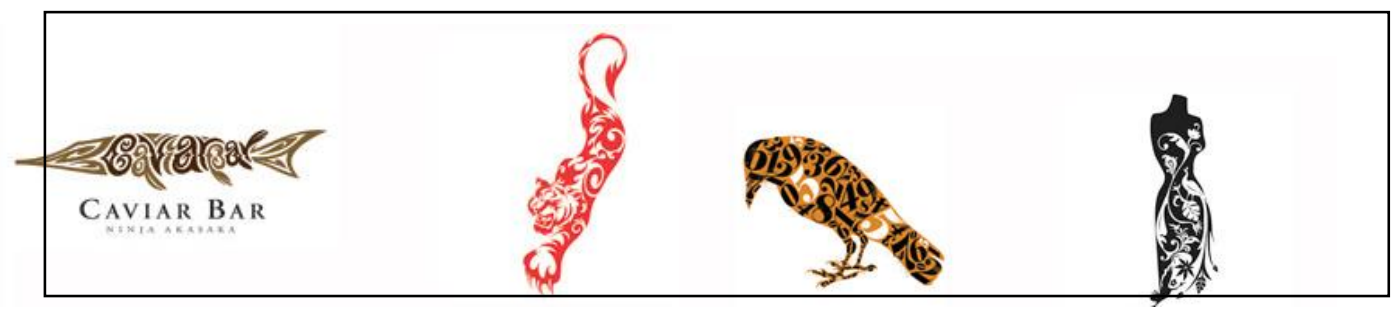




\section{Monologue}

Kata menjadi yang utama dalam gaya visual ini, digunakan untuk menarik perhatian konsumen

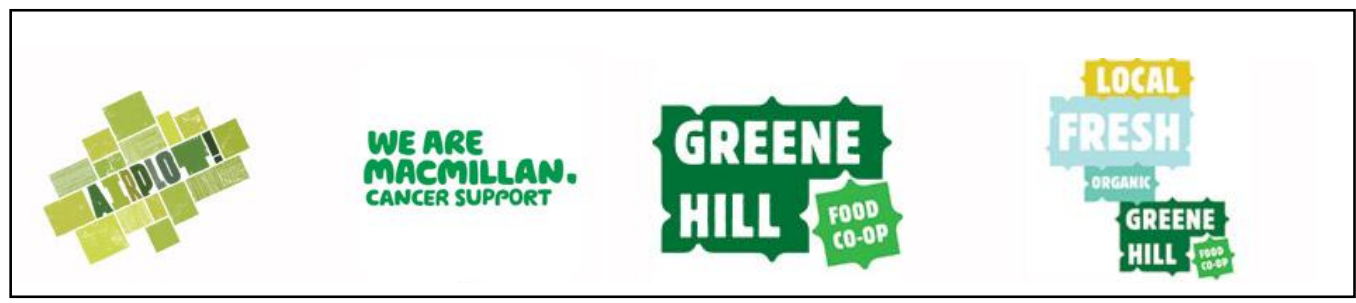

Gambar III. 11 Logo dengan gaya visual Photofill

Sumber:http://www.logolounge.com/article.asp?aid=kfP (3 Januari 2011)

\section{Doily}

Gaya Embellish muncul ditahun-tahun awal ditemukannya mesin cetak, namun saat ini gaya ini muncul dan digunakan.

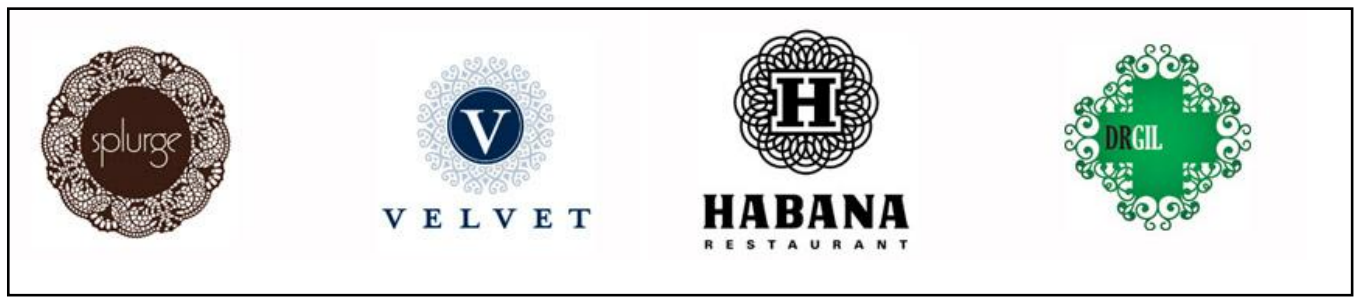

Gambar III. 12 Logo dengan gaya visual Photofill

Sumber:http://www.logolounge.com/article.asp?aid=kfP (3 Januari 2011)

\section{Flip Flop}

Tahun ini Dan Brown's merilis film dengan judul "Angels and Demons." Memunculkan tema "inversion solutions", solusi kebalikan

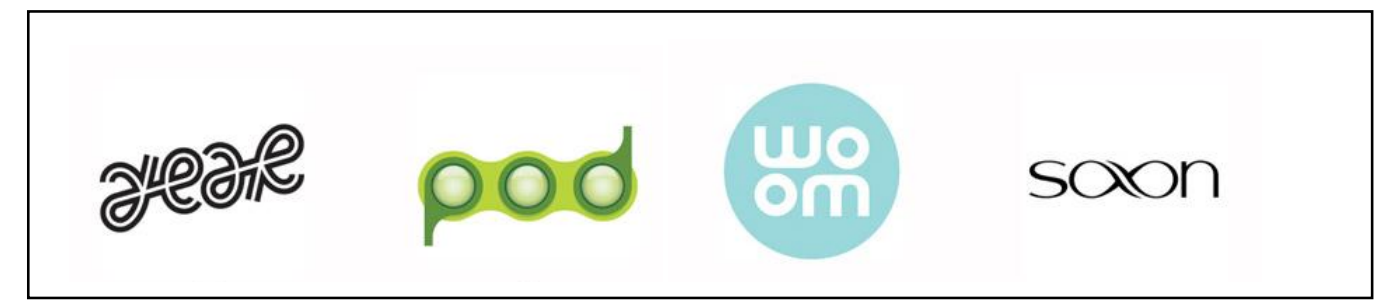

Gambar III.13 Logo dengan gaya visual Photofill

Sumber:http://www.logolounge.com/article.asp?aid=kfP (3 Januari 2011) 


\section{Mosaic}

Epluribus unum: "Out of many, one" Motto ini membantu memunculkan ide tentang mosaic berwarna. Teknologi berubah dan perkembangan akan kebutuhan warna RGB dibeberapa perusahaan membawa pengaruh dan menciptakan konsep visual logo-logo tersebut.

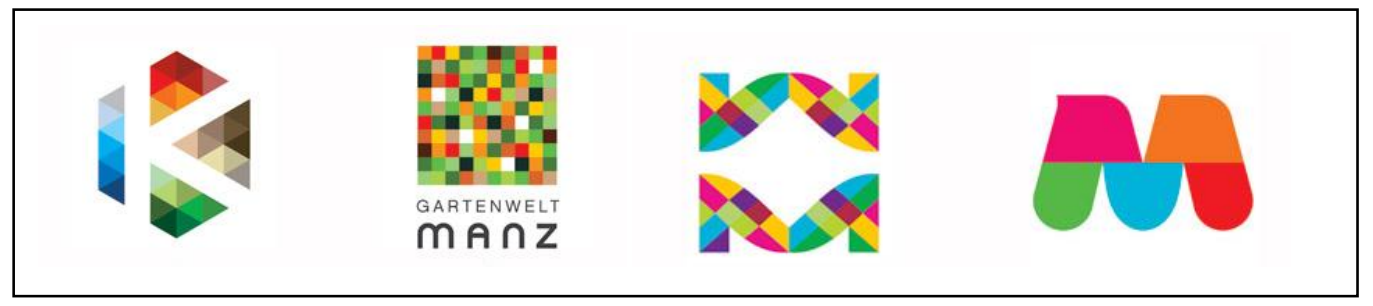

Gambar III. 14 Logo dengan gaya visual Photofill

Sumber:http://www.logolounge.com/article.asp?aid=kfP (3 Januari 2011)

\section{Sequential}

Kondisi sosial masyarakat mempengaruhi gaya visual ini. Kebutuhan terhadap transparansi dalam hal ekonomi, pemerintahan dan individu di masyarakat menjadi ide konsep gaya ini.

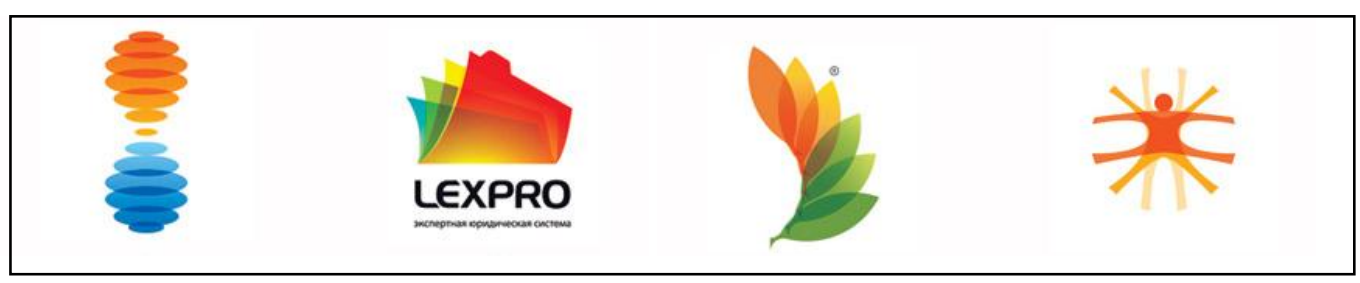

Gambar III.1 5 Logo dengan gaya visual Photofill

Sumber:http://www.logolounge.com/article.asp?aid=kfP (3 Januari 2011)

\section{Recycle}

Gaya visual ini dipengaruhi oleh pertimbangan ekologi. Beberapa perusahaan memahami bahwa kebijakan kelanggengan bukan lagi mantra yang dimunculkan untuk menentramkan konsumen atau publik. Dalam beberapa dekade segelintir 
perusahaan berusaha untuk menciptakan kebijakan dan praktek tanggung jawab pada lingkungan (Green Design)

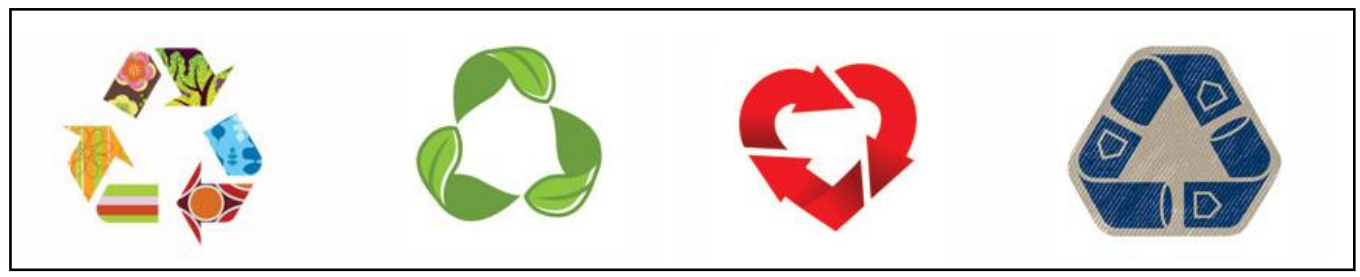

Gambar III.13 Logo dengan gaya visual Photofill

Sumber:http://www.logolounge.com/article.asp?aid=kfP (3 Januari 2011)

\section{Dandelion}

Bunga Dandelion menyebarkan benihnya saat ia kering. Proses ini menjadi daya tarik dan menjadi ikon simbol dalam solusi desain logo.

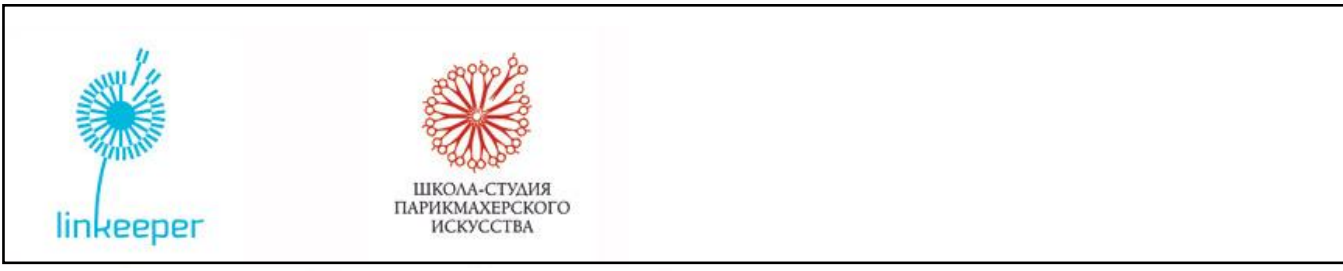

Gambar III.14 Logo dengan gaya visual Photofill

Sumber:http://www.logolounge.com/article.asp?aid=kfP (3 Januari 2011)

\section{Circulate}

Sirkulasi menunjukkan keabadian. Konsep ini menjadi ide dalam gaya visual logo.

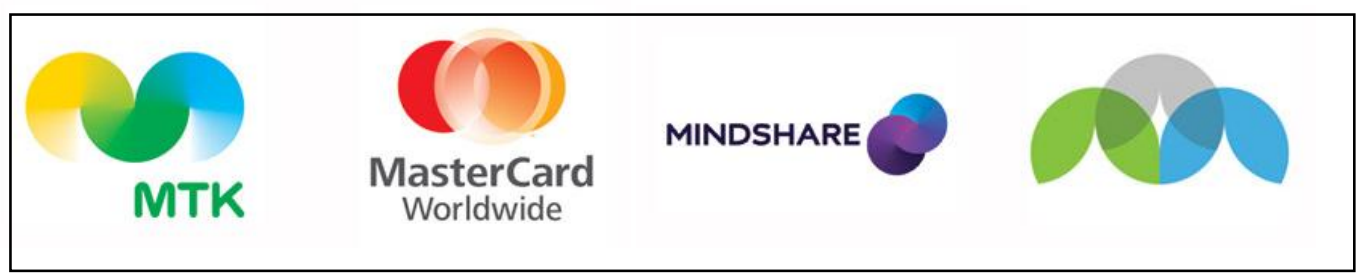

Gambar 15. Logo dengan gaya visual Photofill

Sumber:http://www.logolounge.com/article.asp?aid=kfP (3 Januari 2011) 


\section{Gossamer}

Evolusi, blur menunjukkan gerakan. Konsep tersebut muncul dalam gaya visual logo ini.

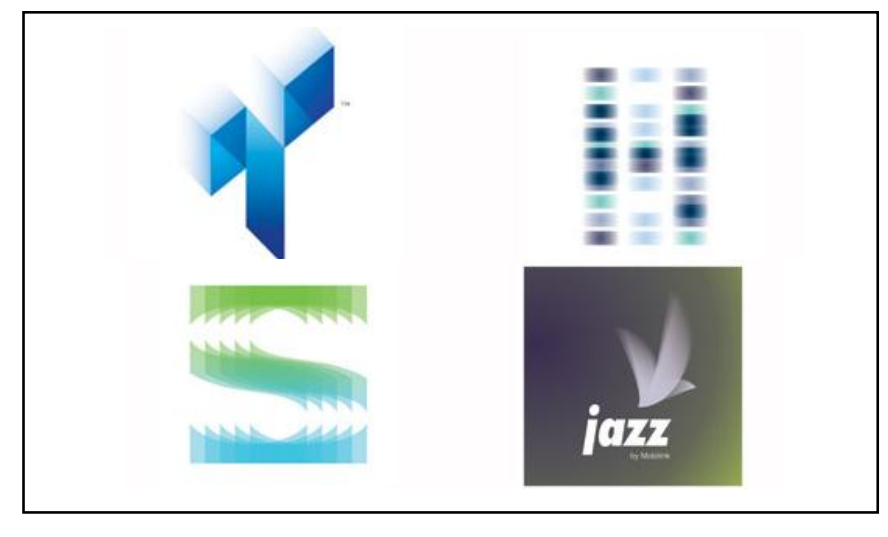

Gambar III.16. Logo dengan gaya visual Photofill Sumber:http://www.logolounge.com/article.asp?aid=kfP (3 Januari 2011)

Bagi seorang desainer dituntut untuk dapat menciptakan desain yang tepat menurut Bryan Lawson (1980, h.119):

“Tugas utama desainer adalah membantu menciptakan sebuah dunia masa depan, dan dalam tugasnya tak pelak lagi terusik oleh banyak keraguan dan ketidak pastian. Sejauh manakah karyanya akan diterima dengan baik oleh klien dan pengguna, dan apakah karyanya akan memenuhi kebutuhan mereka? Bagaimanakah penjualannya dan sampai kapankah karyanya akan awet?"

Point akhir dalam kalimat tersebut adalah tentang "longevity design", bagaimana desainer mampu menciptakan karya yang bersifat kekal. Termasuk dalam merancang logo, menurut Adam Morioka (2004, h.21) ada 10 aturan untuk membuat logo yang baik salah satunya adalah logo harus berumur panjang, kekal (bersifat longevity). Karena setiap saat manusia disuguhi dengan berbagai macam tampilan visual yang beragam, billboard dan sign, iklan televisi, iklan majalah, pesan dalam kemasan, internet dan segala media visual menghujani fikiran. Semua pesan terkadang dikombinasikan dengan logo, namun semuanya berdampak kecil dan terlupakan. Adam menyatakan bahwa gaya dan tren visual 
VISUALITA, Vol.2 No.1 - Februari 2010 : 1-28 ISSN : 2301-5144 (online)

http://visualita.unikom.ac.id/

mungkin menggoda namun ia akan memiliki gaung emosi (emotional resonance) yang rendah yang membuat logo cepat terlupakan. 


\section{ANALISIS}

Zaman akan selalu berubah, semua orang senang dengan jalan pintas, sesuatu yang instan, sederhana dan tidak rumit. Beberapa logo sederhana dan sangat modern, namun lainnya mempunyai gaya visual yang masih konvensional, rumit dan kompleks. Dalam hal ini pengaruh trend sangat kuat. Terlepas dari kriteria baik-buruk, berhasil atau tidaknya sebuah desain logo penulis mengangkat studi kasus beberapa logo institusi pendidikan di Indonesia. Dalam analisis ini penulis menggunakan melakukan analisa pada beberapa logo universitas di Bandung sebagai studi kasus berikut uraiannya.

\section{Logo Unikom}

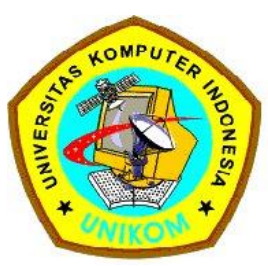

Gambar IV. 1 Logo UNIKOM

Sumber: www.unikom.ac.id (26 Desember 2010)

Arti dan filosofi logo Unikom, dalam buku panduan mahasiswa Unikom 2006

- Bingkai Segi Lima

Melambangkan UNIKOM berlandaskan falsafah negara yakni Pancasila dan Undang-Undang Dasar 1945.

- Lingkaran Dalam Segi Lima Tempat Tulisan Berwarna Kuning

Melambangkan motto UNIKOM menuju kejayaan yakni Quality Is Our Tradition

- Bulatan Dalam Berwarna Biru

Melambangkan UNIKOM bertujuan menghasilkan ilmuwan unggul dan berpikiran maju yang bertaqwa kepada Tuhan Yang Maha Esa.

- Komputer

Melambangkan ciri utama UNIKOM yang memberikan pendidikan teknologi informasi dan komputasi pada seluruh jurusan yang ada dilingkungan Universitas Komputer Indonesia, menjadi universitas terdepan dibidang teknologi informasi dan komputer serta sebagai universitas komputer pertama di Indonesia.

- Stasiun Relay 
Melambangkan UNIKOM menyelenggarakan pendidikan tinggi kearah masyarakat industri maju dengan sistem pendidikan yang kondusif dan tenaga pengajar berkualitas untuk menghasilkan lulusan-lulusan terbaik.

- Satelit

Melambangkan UNIKOM berwawasan global dan menjadi pusat unggulan dibidang IPTEK \& seni yang mendukung pembangunan nasional serta berorientasi pada kepentingan masyarakat, bangsa dan negara.

- Cakrawala

Melambangkan indahnya menggapai cita-cita dan mengejar ilmu setinggi langit.

- Buku

Melambangkan sumber ilmu yang tiada habis-habisnya.

Dalam logo tersebut beberapa elemen visual dimunculkan dengan gamblang, seperti monitor, buku, satelit, yang memiliki makna seperti yang dijelaskan. Beberapa bentuk digunakan sebagai perlambang. Dalam logo tersebut semua ikon teknologi dimunculkan. Ikon-ikon tersebut dikomposisikan sedemikian rupa. Tidak ada penyederhanaan bentuk yang berarti dari objek-objek seperti monitor, antenna, buku, satelit, stasiun relay dan lain-lain, semuanya terwakilkan dengan jelas tanpa ada reduksi, simplifikasi, atau penyederhanaan yang berarti, semua terjelaskan dalam teks berupa visual dan verbal. Masyarakat yang menjadi target sasaran menjadi kunci dalam hal ini, mereka percaya dengan kejelasan visual.

Karakter gaya visual logo tersebut masih sangat konvensional. Selain itu beberapa bentuk yang menjadi bagian dari logo masih bentuk awal dibuatnya benda tersebut. Salah satu contohnya adalah gambar monitor yang ada pada logo tersebut. Bentuk monitor kini sudah berubah, dari bentuk cembung menjadi bentuk flat.

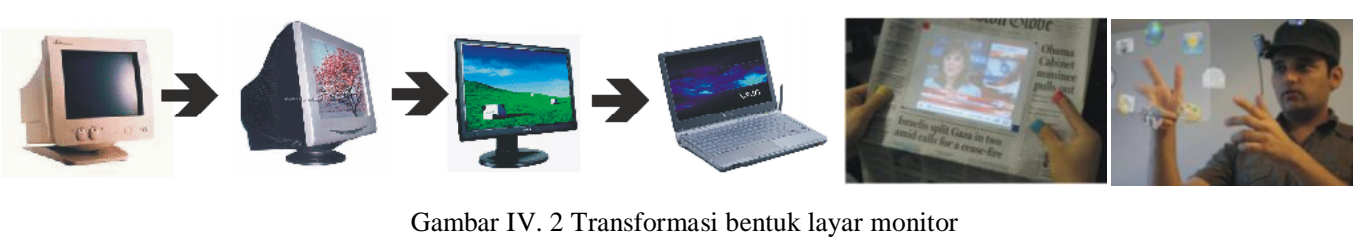

Program Studi Desain Komunikasi Visual, Universitas Komputer Indonesia 
Sumber: http://inet.detik.com/read/2009/06/01/124932/1140601/317ldjljkll (3 Januari 2011) http://www.ssidisplays.com/touch-screens (3 Januari 2011)

http://www.core77.com/blog/technology/mits_wearable_sixth_sense_device_turns_any_surface_into_an_interface_13084. asp (3 Januari 2011)

http://nitkblog.in/note-on-sixthsense-device-by-pranav-mistry/ (3 Januari 2011)

Jika bentuk tersebut disesuaikan dengan kondisi sekarang maka bentuk monitor tersebut dirasa sudah usang. Berikut analisa logo berdasar pada teori yang dikemukakan oleh Carter (2005) dan Gregory Thomas (2000, h.18):

- Original \& Desctinctive,

Dalam hal kekhasan dan keunikan logo ini akan terasa generik karena memiliki kekhasan yang sama dengan logo universitas lain di Indonesia.

- Legible

Keterbacaan yang rendah bahkan untuk ukuran emblem yang disematkan pada pakaian sekalipun. Logo ini memiliki tingkat keterbacaan yang sangat rendah.

- Memorable.

Tidak mudah diingat, bahkan dalam waktu yang cukup lama

- Easily associated with the company

Logo sangat mudah diasosiasikan namun terasa usang saat bentuk monitor kini sudah berubah.

- Easily adaptable for all graphic media.

Logo sulit diaplikasikan dalam bentuk 3 dimensi

Analisa menurut Gregory Thomas (2000, h.18),

- Visibility

Logo menonjol pada lingkungan sekitar namun sulit untuk dilihat dengan jelas jika logo dalam ukuran kecil

- Application

Sulit diaplikasi dalam bentuk 3 dimensi, terkecuali jika logo berukuyran sangat besar

- Distinctiveness

Kompetitor banyak yang memiliki logo dengan bentuk serupa

- Simplicity/Universality

Tidak sederhana, dan sangat regional (khas bentuk logo institusi pendidikan di Indonesia)

Program Studi Desain Komunikasi Visual, Universitas Komputer Indonesia 
- Retention

Cukup berkesan jika dilihat namun bukan respon positif

- Color

Sulit diaplikasikan dalam hitam putih

- Descriptiveness

Logo sangat menggambarkan visi misi namun terkesan berlebihan

- Timelessness

Belum dapat diketahui logo ini mampu bertahan dalam waktu yang lama, namun teknologi sudah berubah dan citra logo terasa usang

- Modularity

Mampu diadaptasikan dalam berbagai apliksi namun dengan upaya yang tidak mudah.

\section{- Equity}

Logo sudah menjadi cirri khas yang cukup kuat, namun belum dapat diketahui sehingga harus berubah.

Terlepas dari hal di atas logo ini cukup dapat merepresentasikan Unikom sebagai universitas dengan ciri teknologi informasi sebagai keunggulannya pada khalayak sasaran, dibuktikan dengan banyaknya minat mahasiswa ataupun orang tua yang memasukan anaknya untuk mendapatkan pendidikan di universitas ini.

\section{Logo Universitas Maranatha}

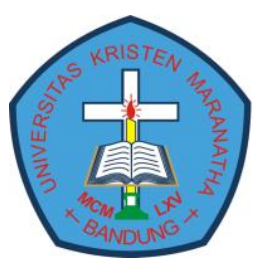

Gambar IV. 3 Logo Universitas Maranatha

Sumber: http://www.maranatha.edu/about-us/identitas-maranatha (26 Desember 2010)

Arti logo Universitas kristen Maranatha menurut situs resminya:

Dasar segi lima warna biru : berarti Dasar Negara Pancasila

Salib : berarti Penyelamatan dalam Yesus Kristus 


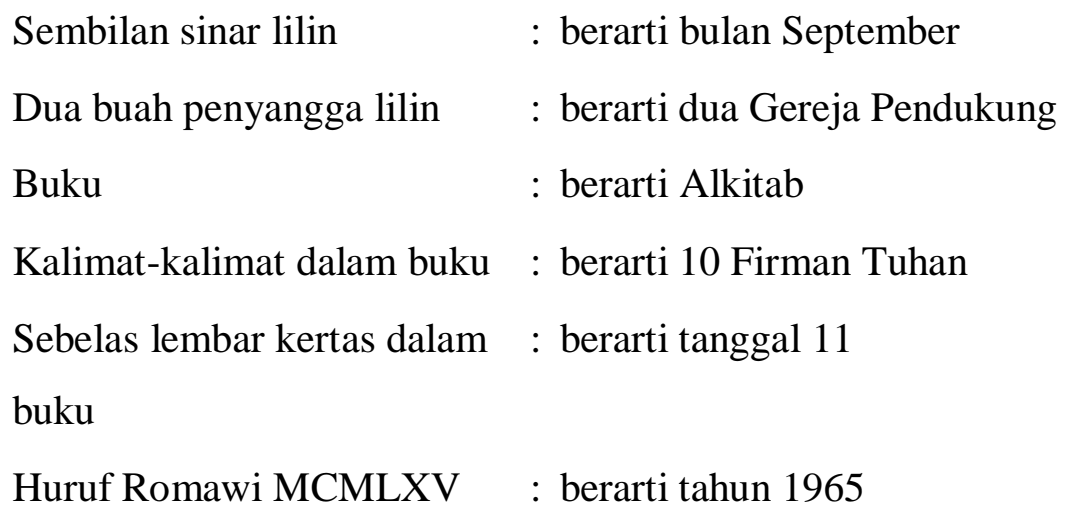

Dengan demikian arti dan makna lambang tersebut di atas adalah:

Universitas Kristen Maranatha (Maranatha = Tuhan Datanglah) yang didirikan pada tanggal 11 september 1965 didukung dua gereja (Gereja Kristen Indonesia Jawa Barat dan Gereja Kristen Pasundan) berlandaskan Pancasila dan UUD 1945, menyelenggarakan pendidikan tinggi atas dasar kasih Yesus Kristus untuk menghasilkan lulusan yang bertaqwa kepada Tuhan Yang Maha Esa, berjiwa Pancasila, peka terhadap masalah-masalah kemasyarakatan dan mempunyai dedikasi serta tanggung jawab yang tinggi terhadap nusa dan bangsa.

Seperti logo Unikom, logo Universitas Maranatha ini masih konvensional. Bentuk segilima sebagai ungkapan dasar negara kemudian simbol serta ikon dari beberapa objek yang dihadirkan korelasi dengan makna logo masih terkesan tidak sinergis.

Disisi lain ikon-ikon dalam logo ini sangat gamblang menggambarkan apa yang diwakilkannya. Seperti salib sebagai ungkapan penyelamatan dalam Yesus Kristus, yang dapat ditemui pada logo-logo institusi pendidikan Kristen lainnya. Bentuk segilima masih sangat konvensional sebagai perwakilan dari falsafah negara yakni Pancasila dan Undang-Undang Dasar 1945.

Bentuk ini dapat dijumpai di logo-logo institusi pendidikan lainnya. Bentuk segilima muncul pada saat kepemimpinan Soeharto, dan menjadi tren pada logologo institusi pendidikan di Indonesia. 


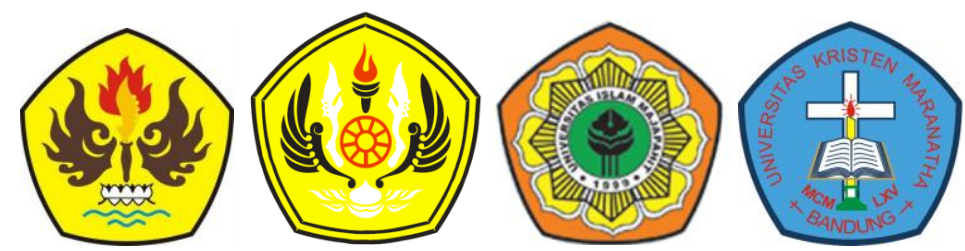

Gambar IV. 4 Logo Universitas Pasundan, Universitas Padjajaran Universitas Islam Majapahit dan Universitas Kristen Maranatha

Sumber : http://unpas.ac.id/profil/makna-lambang-unpas/ http://www.unpad.ac.id/universitas/identitas/logo-unpad/ http://www.unim.ac.id/home

www.maranatha.edu (26 Desember 2010)

Berikut analisa logo berdasar pada teori Carter (2005)

- Original \& Desctinctive,

Dalam hal kekhasan dan keunikan logo ini akan terasa generik karena memiliki kekhasan yang sama dengan logo universitas lain di Indonesia, terlebih pada lambang salib.

- Legible

Logo ini memiliki tingkat keterbacaan yang rendah

- Memorable.

Cukup mudah diingat, namun dalam waktu yang cukup lama

- Easily associated with the company

Logo cukup mudah diasosiasikan

- Easily adaptable for all graphic media.

Logo sulit diaplikasikan dalam bentuk 3 dimensi karena terdapat gambar yang cukup detil

Analisa logo berdasar pada teori menurut Gregory Thomas (2000, h.18):

- Visibility

Logo menonjol pada lingkungan sekitar namun sulit untuk dilihat dengan jelas jika logo dalam ukuran kecil

- Application

Sulit diaplikasi dalam bentuk 3 dimensi, terkecuali jika logo berukuran sangat besar

- Distinctiveness

Kompetitor banyak yang memiliki logo dengan bentuk serupa

Program Studi Desain Komunikasi Visual, Universitas Komputer Indonesia 
- Simplicity/Universality

Tidak sederhana, dan sangat regional (khas bentuk logo institusi pendidikan di Indonesia)

- Retention

Cukup berkesan jika dilihat namun bukan respon positif

- Color

Sulit diaplikasikan dalam hitam putih

- Descriptiveness

Logo sangat menggambarkan visi misi

- Timelessness

Belum dapat diketahui logo ini mampu bertahan dalam waktu yang lama, namun teknologi sudah berubah dan citra logo terasa usang

- Modularity

Mampu diadaptasikan dalam berbagai aplikasi namun dengan upaya yang tidak mudah.

- Equity

Logo sudah menjadi ciri khas yang cukup kuat, namun belum dapat diketahui sehingga harus berubah.

Logo-logo bentuk universitas tersebut masih bentuk konvensional, beberapa menggunakan objek-objek yang disederhanakan dengan sentuhan gaya visual yang diadopsi dari motif serta ragam hias seperti batik. Namun begitu beberapa universitas lainnya sudah menggunakan gaya visual yang lebih sederhana. Gaya visual ini adalah rubahan dari gaya sebelumnya yang masih konvensional.
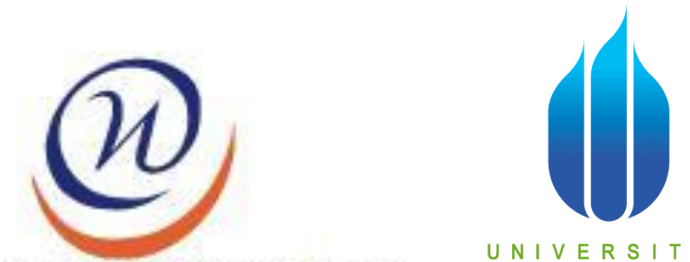

N I VER S I T A S

\section{UNIVERSITAS WIDYATAMA MERCU BUANA}

Gambar IV. 5 Logo Universitas Widyatama dan Universitas Mercubuana Sumber: www.widyatama.ac.id/

http://www.mercubuana.ac.id/modulex.php?id=1 (26 Desember 2010) 
Dapat dibandingkan 2 gaya visual tersebut, logo-logo perguruan tinggi diatas dan logo-logo sebelumnya. Di Indonesia masih sangat banyak sekali logo-logo dengan gaya visual yang sama, tidak hanya logo institusi pendidikan saja tetapi lembagalembaga lain yang tidak berkaitan dengan pendidikan pun menggunakannya. Tidak ada perbedaan unik yang menimbulkan kesan tertentu pada logo-logo tersebut.

\section{KESIMPULAN}

Tren visual selalu berubah, dan mempengaruhi desain logo. Logo yang baik adalah logo berumur panjang dalam penggunaannya, ia dapat bertahan dalam perubahan trenyang ada. Tren hanya bertahan beberapa waktu saja, ia akan selalu berubah tergantung kondisi sosial-budaya masyarakat, oleh sebab itu desain yang mengikuti tren pada beberapa kasus akan cepat usang. Logo yang tidak tetap dan berubah-rubah dari segi ekonomi (bisnis) tidak efektif, karena melibatkan banyak aspek. Ketika logo berubah saat itu pula bisnis dipertaruhkan. Namun kebutuhan perubahan sebuah logo tidak dapat dipungkiri juga dapat berakibat baik.

Secara visual, desain logo yang mengikuti tren akan terasa generik, karena secara emosional ia tidak memberikan kesan yang berbeda bagi konsumen atau khalayak. Teknologi merupakan tools yang mengkomodir kebutuhan desainer, digunakan untuk merealisasikan konsepsi ide seorang desainer. Desain yang baik bukan desain yang dipenuhi oleh efek yang indah dan terlihat canggih yang dapat direalisasikan oleh teknologi, namun bagaimana desain itu menjadi solusi dari sebuah masalah.

Logo menjadi representasi identitas yang menyangkut komunikasi berupa isi, cara, dan gaya. Ia menjadi identitas utama yang menyangkut prilaku; pikiran, kepribadian dan sikap, serta menyangkut nama, format dan kemasan. Oleh sebab itu ia (logo) harus mampu bertahan, tidak terpengaruh tren dan mampu menjadi kebanggaan penggunanya. 


\section{DAFTAR PUSTAKA}

Elliot, Stephen N et al,. 1996. Educational Pschology. Dubuqe-Iowa: Brown \& Benchmark

Lawson, Bryan. 1980. Bagaimana Cara Desainer Berfikir (How designers think). Yogyakarta: Jalasutra

Morioka, Adam. 2004. Logo Design Work Book- A hands on-guide to creating logo. Massacussets-USA: Rockport Publishing

Olins, Wally. 1989. Corporate Identity, Making business strategy visible through design. Toledo-Spain: Thames \& Hudson

Pildicth, James. 1970. Communication by Design, A study in corporate identity. Maidenhad-Brekshire-England: McGraw-Hill Publishing.

Schmit, Berd \& Simonson, Alex. 1997. Marketing Aesthetic. New York-USA: The Free Press

Thwaites, Tony. et al 2002. Introducing Cultural and Media Studies, Sebuah pendekatan semiotika, Yogyakarta: Jalasutra

Vejlgaar, Henrik. 2008. Anatomy of Tren. USA: McGraw-Hill Publishing

Gardner, Bill. 2009. Current Logo Tren, 2009 Tren. Artikel online, http://www.logolounge.com/logotrens/default.asp? Archive $=$ True $\&$ ArticleID $=68$ O (diakses: 12 Desember 2009)

Wheeler, Alina. 2009. Designing Brand Identity: An Essential Guide For The

Entire Branding Team. Hoboken, New Jersey: John Willey \& Son. Inc.

Carter, David. E. 2005. Logo Redesigned: How 200 Companies Successfully Changed Their Image. New York: Harper Collins. 
VISUALITA, Vol.2 No.1 - Februari 2010 : 1-28 ISSN : 2301-5144 (online)

http://visualita.unikom.ac.id/

Carter, David. E. 2005. The Big Book Of Logo I, II, III. New York: Harper Collins.

Lip, Evelyn. 1996. Desain dan Feng Shui. Jakarta: PT Elex Media Komputindo. 